O mapeamento realizado abarca os conteúdos das peças, os discursos acerca da dramaturgia presentes nas crônicas de Nelson Rodrigues e os conteúdos comunicados pela opinião pública através de jornais e revistas que dizem respeito ao teatro rodrigueano. $\mathrm{O}$ entendimento da dramaturgia rodrigueana pareceu mais claro ao se pensar as conexões com os interlocutores do autor. Portanto, pôdese reconstruir como a recepção positiva, as críticas e as censuras foram elementos que participaram da configuração e da construção das peças de Nelson Rodrigues, por também estarem envolvidas na criação de sentidos e valores.

Palavras-chave: Nelson Rodrigues, teatro, comunicação artística, imaginário, opinião pública, recepção.

\title{
Análise das relações reciprocitárias em cooperativas de catadores de lixo de Brasília
}

Pedro Henrique Isaac Silva

Data da defesa: 19 de março de 2007

Nome do curso: Mestrado em Sociologia

Orientadora: $\operatorname{Prof}^{\mathrm{a}} \mathrm{Dr}^{\mathrm{a}}$ Christiane Girard Ferreira Nunes

\section{Resumo}

Para verificar como as relações reciprocitárias se manifestam em quatro cooperativas de catadores de materiais recicláveis, levando em conta suas interações com a organização de trabalho e com as instâncias democráticas, foram utilizados dois referenciais 
teóricos principais: o paradigma da dádiva, referencial teórico que se propõe a entender as dinâmicas sociais a partir das relações que se estabelecem através da tríplice obrigação da dádiva - dar, receber e retribuir -; e a psicodinâmica do trabalho, que procura compreender, a partir da análise do confronto dos sujeitos com a organização do trabalho, como se constrói a subjetividade do trabalhador.

Ao contextualizar as questões do lixo e da reciclagem, da posição social ocupada pelos catadores e da Economia Solidária como alternativa de integração social, nota-se que a situação vivida pelos catadores de materiais recicláveis está evidentemente marcada pela exclusão e pelo estigma social, além da vulnerabilidade econômica. A organização em um empreendimento de Economia Solidária objetiva, então, recuperar o tecido social do qual o catador faz parte a partir dos valores de solidariedade, cooperação, democracia e igualitarismo.

A pesquisa mostra a situação de precariedade dos catadores, as formas de organização das cooperativas, o funcionamento das instâncias democráticas e as relações reciprocitárias existentes entre os catadores, entre estes e a liderança e dos empreendimentos com atores externos à cooperativa. Percebe-se que a mobilização subjetiva dos catadores está intimamente ligada à maneira como essas relações são tecidas e depende, sobretudo, da possibilidade da construção coletiva de um corpo deontológico e normativo que regule as relações de trabalho e permita a cooperação entre os sujeitos envolvidos. Além disso, vê-se que o estabelecimento de redes que privilegiem a construção de elos horizontais permite o fortalecimento mútuo e a manutenção da autonomia dos empreendimentos.

Palavras-chave: Economia Solidária, dádiva, subjetividade, reciprocidade, catadores. 